\title{
The Shape of Life the Shape of Art, Context and Maya Women's Weaving
}

\section{Julia Kellman}

Context, it came to me one morning while putting out corn for the squirrels, is a kind of narrative itself; it has a beginning, middle, and end. It is a story which includes the long, broad sweep of history and the complex, small intricacies of usual setting; it describes routine activities and interactions, illustrates the shape and color of physical place, and reveals the approaching indistinct outlines of future events. Narrative is the great block of an individual's life matrix spun out into various shining threads, like a spider throwing its web, creating pattern and form from dark unobservable recesses, generating silvery lines that describe both structure and a universe.

Every individual is imbedded in the substance of life like an insect in amber, suspended and held forever in the red-gold material, contained, immersed, encased in the very content that defines them and within which they function. To come to know individuals or some aspect of their existence, it is essential to comprehend the setting in which they have their being. To begin to comprehend the huge shape of life's context, its narratives must first be isolated and spun, forming bright strands of meaning that yield insight into the richness of an individual existence unfolding, growing, and extending within the boundaries of an individual world.

Elena Ixcot, a Mam speaking Maya woman from the Western Highlands of Guatemala, was kneeling gracefully on the living room floor of my friend, Irma Otzoy. She was seated on her heels in her elegant, bright colored, traditional clothing or traje, in a posture that was to become familiar to me during my two summers in Guatemala. She was pleased to hear that I planned to investigate women's weaving of huipiles or traditional blouses since she herself was a weaver, but she was also firmly cautionary. Researchers and others from outside Guatemala always overlooked the context of weaving she pointed out. They were interested in how weaving was done she said, or in what the images meant, or in its many colors and complicated technique, but not in the woman who produced it, her history, or in the actual facts of Maya life. In her soft voice she remarked that understanding the weaving of huipiles was impossible without understanding the world of their origin and use. She was determined that I come to see the issue of Maya weaving from her point of view.

This conversation helped to direct me from the very beginning of my research into an interest in the personal narratives of three women who generously shared with me their time and weaving expertise, answered my endless questions, included me in their families and activities, and became my 
friends. These women, from three Cackhiquel speaking Maya communities in the Guatemalan Highlands, provided not only a clear view of their personal approach to weaving huipiles, but showed me the complexities of why such work was produced and how it functioned within their world.

What follows is an excerpt of my examination of the context of Maya weaving set within the narrative of Petrona Mejia Chuta at the point where hosts and guest relax at last into the warmth, pleasure, and safety of our mutual humanity in the tiny village of Saquitacaj near San Jose Poaquil.

Dinner, pitch darkness, and the end of my questions arrive simultaneously. The family drifts toward the kitchen. Francisco, the father, again taking charge, invites me to wash in the pila, or outdoor cement sink. I scoop the cold water from the central holding tank into a small, round, red plastic hand basin, splash my face and scrub my hands, using my blue denim skirt as a towel. Refreshed, I enter the wonderfully warm kitchen, illuminated by the fire in the opposite corner and full of the rich smells of our meal. Felipa, the mother, has spent the time since my arrival here and, indeed, will begin laboring in this small space again at 4:30 the next morning in order to ensure a breakfast that includes fresh tortillas, just as other traditional Maya women do every day of their lives.

To the right of the door on the short end wall is a low platform of bricks that holds a pan of dishwater and extra plates, bowls, cups. The fire, with a comal, or griddle, made from the lid of a fifty gallon drum, shares this same wall and the brick sides of the hearth extend nearly half of the way along the rear wall as well. A small window opening, now closed with a rough shutter, overlooks the slope of trees that tilt both north and east, close behind the kitchen, temescal or sweat bath, and nearby rabbit hutch. Below the window and running to the corner opposite the fire are rickety shelves stacked with foodstuffs and cooking supplies. In front of these, squeezed into the tiny space left in front of the door and below another window, also closed now to the night air, are the table and two long benches. A chair has been fitted in at either end to give additional seating. The tight quarters and hot, smoky air feel good, safe, warm, reassuring, enclosed against the world, a tiny island of light in a sea of blackness. Far away, but hooked into a powerful P.A. system, the insistent voice of an evangelical preacher, a now not uncommon presence even in an out-of-the-way community such as this, exhorts without ceasing until hours later we are all finally in our beds. This born-again Christian movement is responsible for the breakdown or splintering of many aspects of traditional communal life, since it fragments the traditional community-wide religious celebrations and rituals, introduces conflicting dogma, and divides families through the introduction of differing social and religious values. It threatens to become more powerful in the future in this traditionally Catholic country. The sermon stirs the dogs and they bark without pause, agitated by the tone of the endless description of eternal damnation or endless bliss.

Working Papers in Art Education 1991 
One tiny dark colored taper has been gotten from somewhere by my fourteen-year-old friend, Petrona, and Eulalia, her cousin; slightly breathless they dash in the door to install it with wax on a saucer placed in the center of the table. Francisco indicates that I should take the chair with its back to the fire. He sits opposite, his father close on his left on a bench. The children filter into the remaining places. Throughout the meal, Felipa silently serves as other Maya women do, baking tortillas, passing beans, greens, sweetened coffee, cheese, tomato salsa over my shoulder, washing dishes in a large orange plastic pan and placing them in another to drain, for there are not enough to serve the meal. I am given the only cup and saucer since I am a guest. The children have their coffee in small pitchers of various designs. Felipa herself eats while standing as she works in the flickering light.

Among the foodstuffs I have brought, banging on my legs every inch of the way from Antigua in a blue string bag, are two sweet breads, lemon and pumpkin. Francisco cuts the pumpkin loaf into huge hunks with his pocket knife and places them on a plate at the start of the meal. After we are seated he hands a piece to each person at the table. Formally, he thanks me for the bread. His father follows suit in grave tones. No one else in the tiny room speaks. I respond. I feel as if I am a part of a ritual, that we dance like cranes, lifting our long legs, flying up together, bowing. Everyone nibbles then, cautiously, at this unknown thing, not quite certain what it will be like. I hold my breath. At last, they smile. They remark to one another with pleasure in Cakchiquel, and Francisco and his father thank me again for this "cake" which is new to their brown board table. Midway through the meal I am glad to hear Felipa's soft voice asking for her share. She, too, murmurs in pleasure.

We talk of school, our various ages, my studies, the children, and eat until we are all nearly groaning. A tiny alteration takes place in our relationship during this meal. I like their food and know how to eat it. They clearly had fears, especially about the greens. They in turn like my "cake." We are all a little wiser about other humans. Perhaps we are also more real to one another, having shared this little communion.

When the last bits are eaten and the dishes done, Grandfather, Felipa, and Rosa, the youngest child, leave. Francisco remarks as he follows them, "You girls stay and talk." He turns to me, "We have a different bathroom here. I take a bath in fire." He laughs at his good joke about the temescal and steps into the darkness. I can hear them washing together at the pila. Then all is quiet after they enter the tiny adobe and tile building a short way down the slope, except for the preacher and the crazed dogs.

I am exhausted after the long day of buses and Spanish conversation and explain to the young women that I would like to go to bed shortly. Petrona and Eulalia finally escort me, carrying a candle, across the rough ground to the building nearest the road and to Petrona's bed in the front room near the altar; the bed has been made up in fresh, white, coarse cotton sheets, especially for my visit. They find a sleeping bag to open over it and a 
blue quilt, for they are worried that I will be cold and urge me to crawl in immediately; they wish to see me settled before they leave with the light. Still in my coat and all my other clothing except my glasses and sandals, I creep in, hauling the covers over me at the same time. They confer, tug on the blankets, tuck in edges, smooth out wrinkles. Finally satisfied, they wish me good night and leave, plunging me into darkness to listen to the dogs snarling and yapping around the house, the coughing and groaning of Grandmother, who is dying in the next room of asthma and amoebas, the still fervent exhortations from the crackling P.A. of the distant minister bent on saving souls, and also the low conversation of Eulalia, Petrona, and now Felipa, on the narrow porch.

The cold rises like mist into the bed, forcing me to lie with ankles crossed, arms on chest, to conserve heat. An hour later, or perhaps an eternity, the room is bathed again in golden flickering light. I turn my head slowly in my cocoon to see a blur (without my glasses), three shawl-wrapped, dark shapes in a row watching apparently, candle held high, like three women in a monumental frieze, quiet, afraid to wake me, afraid not to, clearly wanting something. Petrona, Eulalia, and Felipa have brought another blanket for they are worried that I am still cold. They carefully fold me in a second time. Again the candle recedes as the women rustle away, the heavy cotton of their skirts sounding like enormous wings beating slowly. Like doves, I think. This time, however, they go to bed as well in the room next door. I can hear the entire family settling into their nests. I am warm at last.

With this meal and bedtime my further understanding of the context of weaving took place, the shape and sounds of night in the Highlands, the sudden darkness of the tropics, the necessary warmth of a heavy cotton huipil, the smell and taste of a supper of black beans, tortillas, cheese, and greens, the security of a kitchen fire on a tall brick hearth, the practice of wearing a huipil inside out to keep it clean, the various roles of men, women, and children, the sense of life lived on a high, windy ridge.

Anne truitt remarked, "Artists have no choice but to express their lives. They have only, and that not always, a choice of process. This process does not change the essential content of their work of art, which can only be their lives" (1982, p. 43). This being so, individual context can be seen in a new light, not as some merely interesting collection of small stories, anecdotal evidence of a life being lived, or details too tiny to count, but as the wellspring of each artist's work. Elena lxcot was right to point out that to understand the weaving of huipiles it is essential to understand the world of their origin and use, for it is within the richness of each weaver's life that a huipil has its genesis, its life, and its reasons for being.

This elaborate, slowly emerging picture of life in the Highlands expanded my sense of the source and setting of Maya weaving and placed it firmly in its world of living women, rich, nourishing, complex, taking part in community, history, and the vast flow of human existence. Without this 
context, the substance of these artist's weavings would dim to mere multi-colored threads worked into complicated patterns; a world would be lost and with it the story of a woman's life.

\section{Reference}

Truitt, A. (1982). Daybook, the journal of an artist. New York: Penguin. 


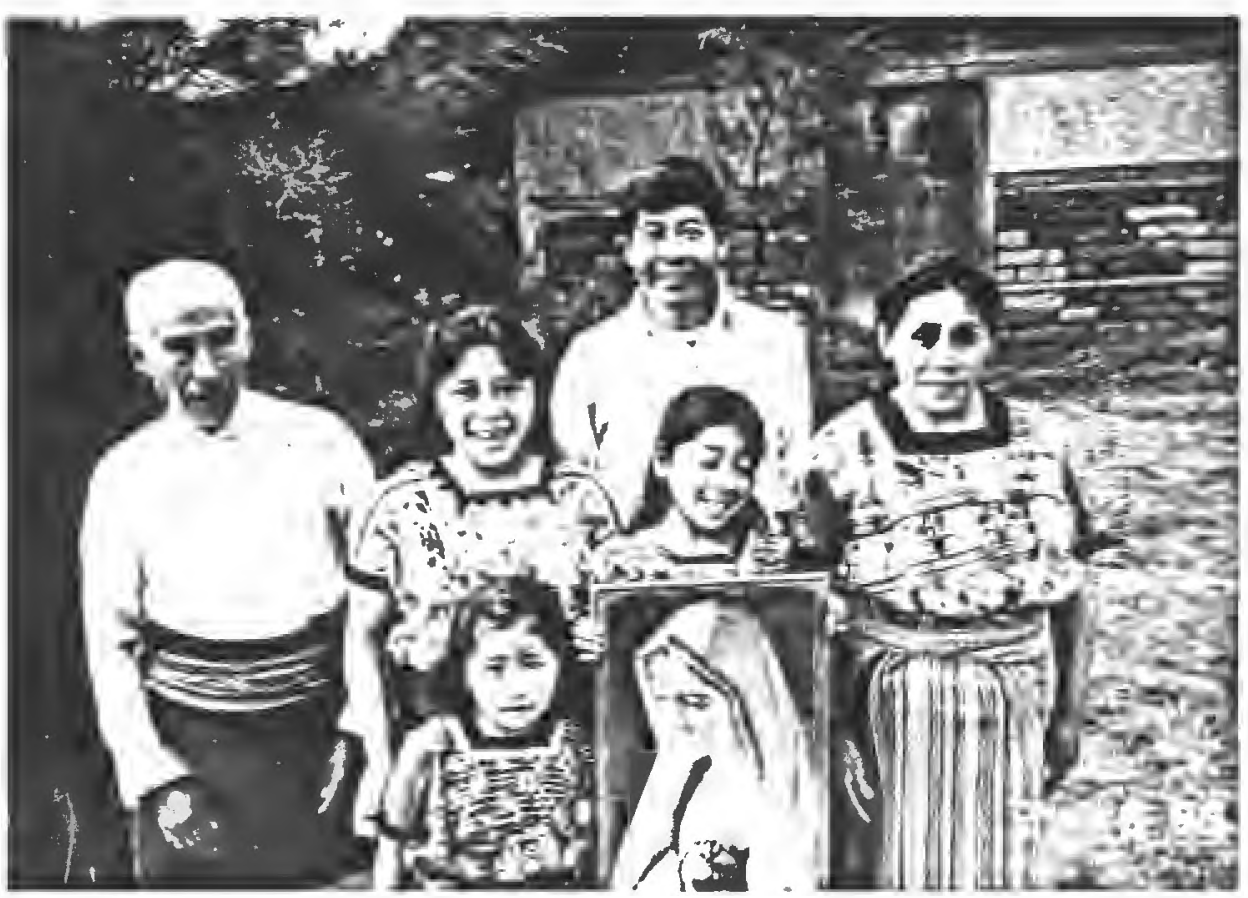

Figure 1. Grandfather, Petrona, Maria, and Felipa with Francisco in back and Rosa in front.



Figure 2. San Jose' Poaquil Market

Working Papers in Art Education 1991 